\title{
建築デザインかるたを用いた建 THE METHOD OF STUDYING A BASIC 築デザインの基礎知識の学習方 KNOWLEDGE OF ARCHITECTURAL 法について DESIGN BY ARCHITECTURAL DESIGN CARDS
}

\author{
篠部 裕 一 $* 1$ \\ キーワード \\ 建築デザイン, かるた, 学習方法, 復習, ゲーム \\ Keywords : \\ Architectural design, Cards, Method of studuying, Review, Game
}

\author{
Hiroshi SHINOBE ——1
}

The carta is a game of cards. It has some effects not only as a game, but also educational method. This paper reports the method of studying architectural design by architectural design cards. The analysis is based on the data of the architectural design cards designed by 34 students and questionnaires for them. Students could enjoy playing the architectural design cards as a game and review the lessons by drawing up these cards. Therefore I could confirm that the architectural design cards is an effective method of studying and reviewing the architectural design.

\section{1、はじめに}

かるたは、わが国の伝統的な室内遊珹具の一つである。教育系か るたの代表である「いろはがるた」は、いろは47文字と「京」のそ れぞれを頭文字とすることわざを合計 48 枚にまとめたもので、「か な」と「ことわざ」の両方を同時に学習できるように作られている。

戦前の小学校では、いろはがるたなどの絵合わせかるたが教具に使 用されていたが、現在でも多種多様な絵合わせかるたは、幼児や児童 を対象に教具や室内遊戲具として広く利用されている。我々の誰もが 何らかの形でこれらのかるたを使って、遊びながら「かな」や「こ とわざ」などを学習してきたに違いない。

字札の頭文字や内容と一致した絵札を探す絵合わせかるたの絵札 は、対象となる物事がイラストや写真などで表現されている。建築の 分野では、情報や意志の伝達が主にスケッチや図面などを介して行わ れるということを考慮すると、絵合わせかるたの様な絵札を制作する ことは、物事の概要を図や絵として適切に表現するための一つのト レーニング方法になると言えるであろう。

そこでこの様なかるたを建策の学習方法に応用するという視点か ら、学生が遊び心をもって建築デザインの基礎知識を学習するため の「建築デザインかるた」の制作に、計画系の科目である建筑意匠 の一演習課題として取り組んだ性1。建筑デザインかるたは、建築意 匠の講義で学習した建築デザインに関する知識や意匠論を参考に、各 学生が自らの文章と絵を用いて建築デザインの基礎知識の要点をまと めるもので、学生は自らが制作したかるたを教具としても活用できる。

本稿は、学生による建築デザインかるたの制作とその評価を通じ て、建築デザインの基礎知識の学習方法について検討するものである。

\section{2、建築デザインかるたの課題内容}

建築意匠の一演習課題である建筑デザインかるたを制作する上で の留意点として以下の 3 つのポイントを学生に示した。

(1)建築デザインを専門的に学習する上で教示性のある内容

(絵・文章) である。

(2)文章の語路がよくすらすら読め、頭に残りやすい。

(3)文章の内容が適切な絵(オリジナルなイラスト) で表現されて いる。

また、個々の学生によって制作される建策デザインかるたの書式 をある程度を統一するために以下の条件を指定した。

(1)札の大きさは、絵札、字札とも䋖 $100 \mathrm{~mm} \times$ 横 $68 \mathrm{~mm}$ (黄金 矩形）とし、厚紙に貼り付けて仕上げる。

(2)字札の文章は 31 字以内でまとめる。

(3)字札の文章の下段に 100 字以内の簡単な解説文を記述する。

以上の課題を呉高専建築学科 4 年生 (34名) に対して、1999年 11 月に出題し、2000 年 1 月に提出してもらった。

制作に当たっては、学生 4 名を 1 グループとし、1グループ毎に 「あ行」から「わ行」までの各一行 (5 文字) をそれぞれ割り当て、 1 人当たり 5 組のかるた（絵札および字札）を制作することを基本 とした。かるたの提出日には 4 グループに分かれ、学生が制作した 計 4 セットのかるたを使用して、約 1 時間程度のかるた大会を実施 した。学生は他の学生によって制作された様々なかるたの絵札や字札 の内容をゲームを通じて鑑賞した。ゲーム中の学生は普段の授業中に は見せない屈託のない笑顔をみせながら、建築デザインかるたを楽 しんでいた。
*1 文部科学省初等中等教育局 教科書調查官・博士 (工学)

（宁100-0013 東京都千代田区霞が関3-2-2）
*1 Specialist for Textbook Examination, Ministry of Education, Culture, Sports, Science and Technology, Dr. Eng. 
3、学生による建築デザインかるたの制作内容

グループ別のかるた大会実施後、各学生が制作した5組のかるたを A3 判用站各 1 枚に張り付けて廊下に一週間揭示した。揭示後、制作 を担当した各グループを 2 グループ毎にまとめ、各自が最も良いと思 うかるたを文字毎に計 10 組（例：あ〜こまでの計 10 文字）、学生相 互で選び、投票した。選考に蔡しては、絵札のデザイン、字札の記述 内容などから総合的に選定してもらうように学生に依頼した ${ }^{\text {2) }}$

表 1は、学生によって制作されたかるたの中から、学生が最も良いと 評価したかるたの字札の内容をまとめたものである。

この演習課題を実施する上で重要なことは、個々の学生における 建筑デザインに関するボキャブラリーやその理解度にある。授業で 学んだ内容の理解度や各自が普段からどれくらいデザインに関する 知識や情報を収集・学習しているかで盛り込まれる内容が決まると 言える。

絵札については、オリジナルのイラストということを指示してい たが、安易にコピーを利用した習作も見られ、この点では絵札のデ ザインを軽視するものが一部にみられた。しかしその一方で、 $100 \mathrm{~mm} \times 68 \mathrm{~mm}$ の小さな平面をコラージュなどの手法により高 密度に仕上げた完成度の高い絵札もみられた。

字札については、卮えたい内容を短い文章として简楔にまとめる ことがポイントとなる。対象の捉え方や整理の仕方、エッセンスと しての内容の要約のトレーニングになる。アンケートによるとこの 短文としてまとめる作業が難しかったとする学生が多かった。五七 五調に限定して考えるとかなり難しいという意見も奇せられた。

今回は、「あ」から「ん」までの五十音を行每に分担して制作し たが、別々の文字でも札の内容がかなり重複する作品も多くみられ た。例えば、「あえて隠して美の空間」や「少しだけ見えそうで見え ない見え鲶れ」や「ん?なんだ? 興味を持たせる見え隱れ」などは、 何れも日本の伝統的な見光隱れのデザイン手法を詠った字札であり、 これ以外にも見え隠れを表現した札が多数みられた。この様にある一 つの事項にかるたの内容が集中する理由は、授業での印象度に関係す るとも考えられるが、学生の建策デザインに関するヴォキャブラリー の貧困さに起因するものと言える。この样な重複をある程度避ける ためには、勿論幅広い思考を促す授業内容や指導方法の工夫が望まれ るが、例えば伝統建権のデザイン、現代建勧のデザイン、家具のデ ザインなどにジャンル分けするなどの工夫も考えられるき33)。しいし 中には、一行 5 文字全ての札を同一の建策家（フランク・ロイド・ラ イト) を対象に、一人の建築家の設計理念と作品の関保をテーマにか るたの制作した優れた習作もみられた。

内容が適切に表現されているか否かについては、ほとんどが正確に 理解され、表現されていたが、一部には誤解を招くものもあった。例 えば「ファサードは自由になったよコルビュジェで」は、コルビュジェ が提唱した近代建筑の五原則の一つを詠ったものであるが、鉄筋コン クリート造という構法を含めた表現にする方が望ましいと言える。よ り短い简澺な文章にしようとする故に、この様な不十分な表見も生じ てくる。従って、この様な場合は、短文の下側に并記された解説文 (100字以内）で補足することとなる。

また、建築デザインかるたであるにも関わらず、「ノギスとは正確 迅速な測定器小、「AE剤混ぜるとすぐに流動化」、「ゆっくりと粒子は 下がり水上がるブリージングには気をつけよう」などの様に建築デザ



军真 1 かるた大会の風量

表 1 学生によって制されたかるたの字札の内容

\begin{tabular}{|c|c|c|}
\hline & 宇札の文章 & 倩青 \\
\hline あ & あえて覀して美の空间 & \\
\hline W & 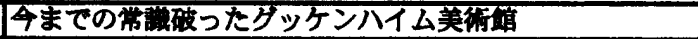 & 1 \\
\hline 5 & うねる天井それはヴィープリ & 1 \\
\hline $\bar{\hbar}$ & 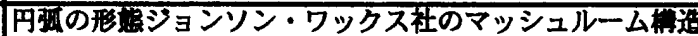 & 1 \\
\hline お & 乓に建つ光の芸骨ロンシャン数会 & $\overline{1}$ \\
\hline か & 家具を宣きそこから娼まるライフスタイル & 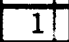 \\
\hline ᄅ & 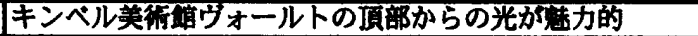 & 1 \\
\hline$<$ & 空間をカプセル化する黒川紀章 & $\overline{3}$ \\
\hline F & 候科した面にそひひえる六甲の集合住宅 & $\overline{2}$ \\
\hline$\Sigma$ &  & $\overline{2}$ \\
\hline さ & 样々な竘果をもたらす空网棈成 & $\overline{1}$ \\
\hline 乙 & 目然との和を目指すF.L.ライト & $\overline{1}$ \\
\hline$\Phi$ & 少したけけ見えそうで見えない見えかくれ & $\overline{1}$ \\
\hline せ & 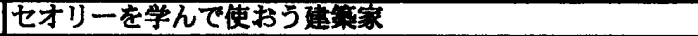 & 1 \\
\hline $\bar{z}$ & 琵站を一切省いたミニマリズム & 1 \\
\hline た & 立ち止まり見るも全てがまだ見えぬ足が先行く見えかくれ & 1 \\
\hline$\overline{5}$ & 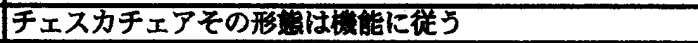 & 1 \\
\hline 5 & 俩合いのとれた状䋈That's シシメトリー & $\overline{1}$ \\
\hline $\bar{\tau}$ & 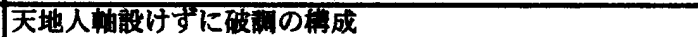 & $\overline{1}$ \\
\hline ह & 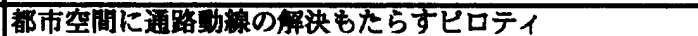 & $\overline{1}$ \\
\hline な & 波のようにうねる天井ヴィーブリ図亥淔 & $\overline{1}$ \\
\hline に & 日光さんさんスカイライト & 1 \\
\hline 2 & 温もりあるライトの建象 & 1 \\
\hline ね & 口わくはいってみたいなパウハウス & 1 \\
\hline の & ノキスとは正碓迅速な㨽定陚 & $\overline{1}$ \\
\hline は & パルテノンその設計に技䚘あり & 1 \\
\hline $\bar{\Xi}$ & 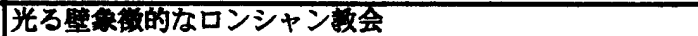 & $\overline{1}$ \\
\hline s & ファサートは自由になったよコルピュシェてて & 1 \\
\hline ^ & 平溥面で表す連䡒性 & 1 \\
\hline ほ & |ほらみんなて椅子になって座ろうよ & $\overline{3}$ \\
\hline ま & Myhome世界に知れ洨る住吉の長㢆 & 2 \\
\hline み & 宮大工匠の技が光ってる & $\overline{3}$ \\
\hline む &  & 1 \\
\hline$\$$ & 目をだまし興味をあおる見えがくれ & 1 \\
\hline छ & モント゚リアン舟何学的な美しさ & $\overline{1}$ \\
\hline p & ヤン・レツェル原鬲ドームの設計者 & $\overline{3}$ \\
\hline$\Phi$ & ゆるやかなスローブとピロティのサヴォイ郎 & 1 \\
\hline よ & ようやったルコルピュシェェあんたはえらい & 1 \\
\hline 5 & 落水荘自然とおりなすハーモニー & 1 \\
\hline b & 利用者は老若男女パリアフリー & $\overline{3}$ \\
\hline 3 & 頡にない造形学校バウハウス & 1 \\
\hline れ & Less is more 過多な巷饰排した空間 & $\overline{1}$ \\
\hline 万 & ロマネスク強固な塈のバシリカ形式 & 3 \\
\hline क & 忘れるな近代戛五原則 & 1 \\
\hline$h$ & ん？なんだ?，味を持たt & - \\
\hline
\end{tabular}

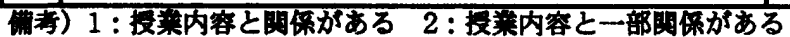
$3:$ 投莱内容と直接は闒保がない 
イン以外の分野を対象としたかるたも一部にみられた。

\section{4、建築デザインかるたの課題として有勃性の検討}

学生によって制作されたかるたの揭示発表と学生によるかるた の選考後、各学生がこの演習課題にどの様に取り組み、どの様に 評価しているかを明らかにするために、本演習課題に取り組んだ 34 名の学生を対象にアンケート調查を実施した。以下、アンケー 卜調查結果をもとに、学生がどの様にこの演習課題に取り組んだ かを简単に考察する。

「かるたを作成する上で、建築意匠で学んだ投業内容を取り入れ ることを意識しましたか」には、意識したが21人 (61.8\%) と最も 多く、かなり意識したも6人いる。授業内容を反映することはかる たの制作上の条件とはしなかったが、結果として約8割の学生が授 業内容を意識しながら本課題に取り組んでいる。次に「かるたを作 成することは、授業で学んだことを復習する上で効果がありました か」には、効果があるが26人 (76.5\%) で、8割近くの学生に復習 上の効果が認められている。前述した授業内容を意識したものは殆 どの学生が復習上の効果を認めている。

絵合わせかるたを制作する上で重要な点は、絵札と字札が一致する 一対のかるたを制作することにある。制作上、絵札と字札のどちらを 中心に考えましたか」には、字札を中心に考えた (18人、52.9\%)が、 どちらも同じくらいに考えた (9人)、絵札を中心に考えた (7人) と 比較して多かった。絵合わせかるたは、字札を読みそれに合った絵札 を探すゲームであるということを考えると、かるたの内容を字札つま り文章から優先して考える学生が全体として多かったというのは当然 の結果とも言えよう。

今回は学生による自作かるたを使ってゲームを実施した。「建築デ ザインかるたをゲームとして実際にやって楽しかったですか」に は、大変楽しかったが 10 人、楽しかったが 19 人で、約 8 割の学生 がゲームとして実際に行うことに満足している。しかし、「建築デザ インかるたをゲームとして実施することは学習上勃果があると思い ますか」には、効果があるとあまり効果がないが半々で、学習上効 果が上がる方法とは言い切れない。今回は絵札の右上に頭文字を記 入することにしたため、せっかく考えた字札の文章の内容をよく聞 いて絵札を探すことよりも、ゲーム中に頭文字そのものを探す学生 が多く見受けられた。字札の内容を如何に適切に絵札に表現するか もこの課題の大きなポイントであり、この点では頭文字を絵札に記 入しないで、字札の文章の内容から絵札を探す方が良いという意見 も聞かれた ${ }^{(4)}$ 。絵合せかるたは字札之絵札が一対で作られるもので あるということを考慮すると、この様な絵札の書式の工夫や改善も 課題出題上、必要と言える。

一方、「建築デザインかるたを演習課題として取り組むことをど の様に思いますか」には、大変よい（2人）と良い（27人）が多く、 全体の8割を越える学生が演習課題として実施することを評価して いる。また、本課題が演習課題として大变良い、良いと回答した学 生に制作上、一番良い点を開くと、「短い文にまとめることで重要な ポイントを簡潔に整理できる点が良い」とする学生が 11 人と最も 多かった。

アンケートにおける建築デザインかるたについての意見、感想、問 題点（自由記入形式）からは、「文を簡潔にまとめる点が難しかった

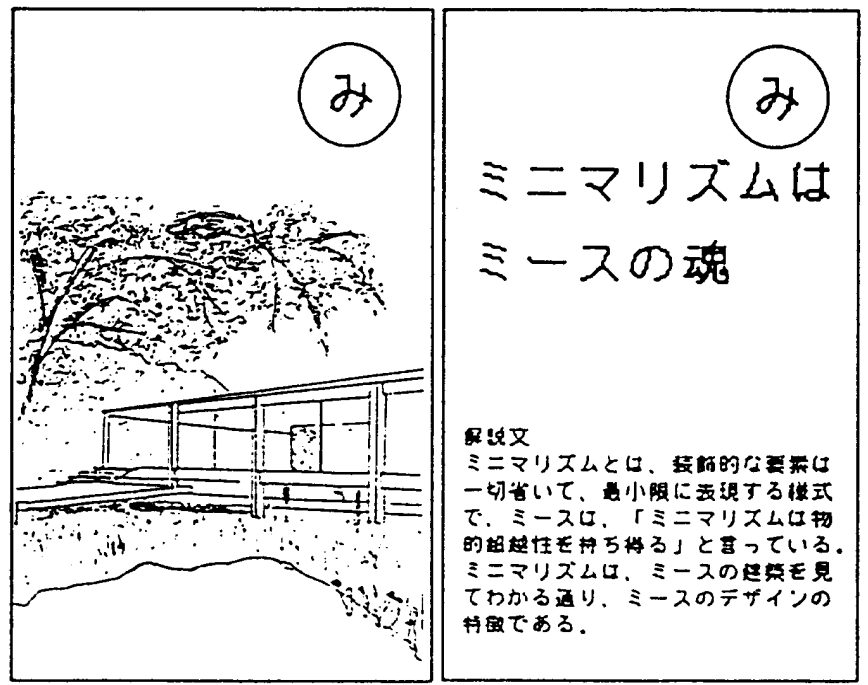

図 1 学生による建築デザインかるたの制作例

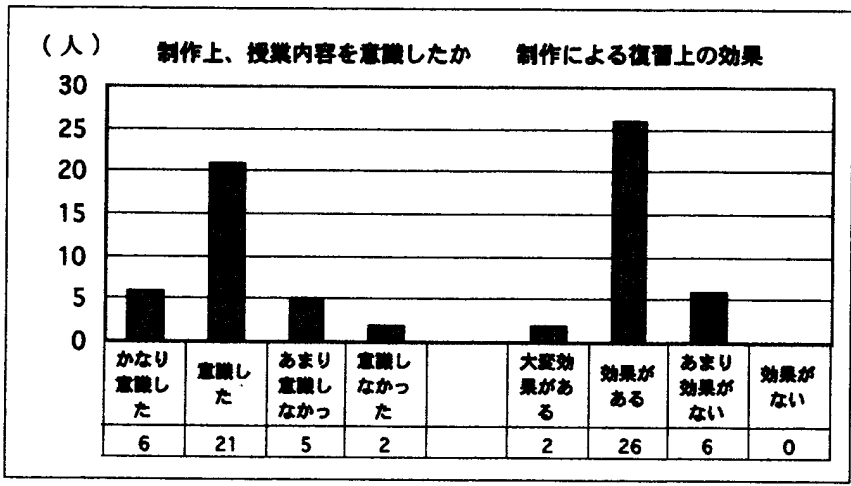

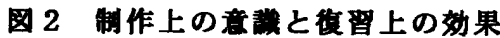



图 3 ゲームとして央施する上ての协果

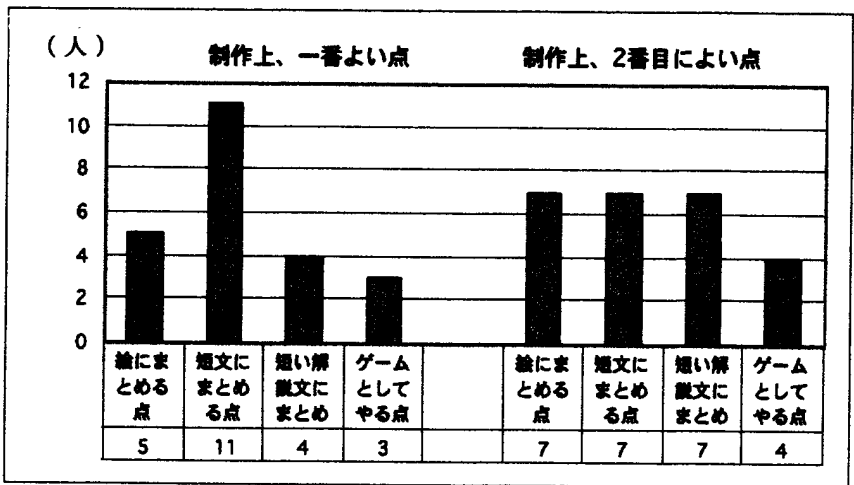

图 4 演習琹題としての良い点 
(多数)」「他と内容がかぶるのが多かったのでつまらなかった（多 数)」、「あいうえおなど五十音に囚われずに自由に作成した方が良い と思った」、建築意匠の内容に限らなくても良いと思う」などの要望 や問題点などのほか、「ゲームはとても楽しかった（多数)」、復習や 自習を自分から進んでやる効果があると思う」、「かるたを制作するこ とで自然と教科書や配られたプリントをもとに作成した」、「これをや ることで建勧に興味がもて、党えていけたのでよかった」などの感想 が上げられた。

5、まとめ

建筑デザインかるたは、制作とゲームがセットになった演習課題 である。学生の殆どは、授業で学習した内容を何らかの形で意識しな がら、この演習課題に取り組んでいた。学生の中には意識的に授業 で習った内容を振り返りながら課題に取り組んだので、復習上有効 であったという感想も聞かれた。この意味では、建築デザインかる たは、一連の摱業や学習を振り返り、学習した内容を整理する上で有 効な演習棵題と言えよう。

また、個々の学生によって制作されたかるたそのものを使ったゲー 厶を実施することで、通常他の学生の習作に関心を示さない学生も 他の学生のかるたと自分のかるたをゲームを通して自然と比較してお り、ゲームの実施はお互いの習作を鑑賞・評価する上でも有効な方 法と言える。

学生によって制作されたかるたは、全体としてボキャブラリーの不 足などから偏りがあった点が否めないが、この点は建築デザインの分 野の中で様々なキーワードやジャンルを紹介、提示するなどしなが ら、多種多様なかるたが制作できるような書式を工夫する必要があ る。一方、かるたの对象を建策デザインの分野に限定せずに制作し た方が良いという意見も寄せられた。この点では、他の専門分野の 科目の学習に応用することも考えられる。建筑デザインかるたは、 建築意匠の講義の一演習課題として実施したものであるが、この様な 課題を繼続して実施し、内容の優れた習作で編集すれば、一つの自作 教具として有効に活用できる可能性もある。

本稿は、建筑の学習方法の一ケーススタティとして、建築を学ぶ学 生が取り組んだ演習課題とその評価についての報告であるが、今後は 様々な演習課題とその評価の蓄積を通して、建筑という専門分野にお ける望ましい学習方法のあり方を検封していくことが必要である。

碀辞 呉工業高等専門学校建築学科の 4 年生 (1999年度) には、資 料の提供とアンケート調査に協力頂いた。ここに記して感謝の意を表 す。

\section{蒲注}

注1) 建築意匠は、吳工業高等尃門学校建築学科における計画䒺の専門科目（開

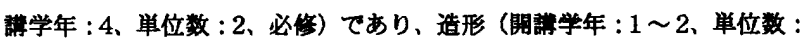

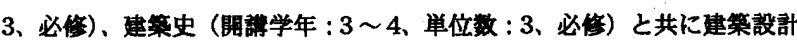


いる。本科目は、主に近代建學の設計事例を題材として、設計理念や設計 手法の基本を学習することを教育目祭としている。建集デザインかるたは、 1998 年度に引き繞き 1999 年度は 2 回目の試みであった。

注 2) 投票結果は学生に示すと共に得票数に芯じて課䞨撞価に加味した。
注3)この样な建策デザインかるたを継繶的に実施すれば、各学生によって㝵由


ための教具（脶えば、コルビュジェ学習かるた）の制作、使用も可能たあ る。

注4)百人一首の様に上の句と下の句を分けた方が良いのではという意見もあっ た。

[2000年 4 月20日原稿受理 2000年 7 月26日採用決定］ 